Review

\title{
Host Restriction Factors Modulating HIV Latency and Replication in Myeloid Cells
} Guido Poli ${ }^{1,3^{*}}$, Isabel Pagani ${ }^{2}$, Pietro Demela ${ }^{1}$, Silvia Ghezzi ${ }^{2} \&$ Elisa Vicenzi ${ }^{2}$

${ }^{1}$ Human Immuno-Virology San Raffaele Scientific Institute, Via Olgettina n. 58, 20132, Milano, Italy

${ }^{2}$ Viral Pathogenesis and Biosafety Units, San Raffaele Scientific Institute, Via Olgettina n. 58, 20132, Milano, Italy

${ }^{3}$ Vita-Salute San Raffaele University School of Medicine, Via Olgettina n. 58, 20132, Milano, Italy

* Correspondence: poli.guido@hsr.it; Tel.: +39-02-2643-4909

\begin{abstract}
In addition to CD4+ T lymphocytes, myeloid cells, and, particularly, differentiated macrophages, are targets of the human immunodeficiency virus type-1 (HIV-1) infection via interaction of gp120Env with CD4 and CCR5 or CXCR4. Both T cells and macrophages support virus replication although with substantial differences. In contrast to activated CD4+ T lymphocytes, HIV-1 replication in macrophages occurs in nondividing cells and it is characterized by virtual absence of cytopathicity both in vitro and in vivo. These general features should be considered in evaluating the role of cell-associated restriction factors aiming at preventing of curtailing virus replication in macrophages and $\mathrm{T}$ cells particularly in the context of designing strategies to tackle the viral reservoir in infected individuals receiving combination antiretroviral therapy. In this regard, we will here also discuss a model of reversible HIV-1 latency in primary human macrophages and the role of host factor determining restriction or reactivation of virus replication in myeloid cells.
\end{abstract}

Keywords: HIV, Macrophages, MDM, restriction factors, transcription factors, macrophage polarization

\section{Introduction. Macrophages as targets of HIV replication.}

The Lentiviridae genus of retroviruses are known to privilege mononuclear phagocytes for their replication although they can also infect other cell types [1]. In the case of the human immunodeficiency virus (HIV), the selection of CD4 as primary entry receptor has evolutionarily determined an expansion of its cell tropism for a major subset of $\mathrm{T}$ lymphocytes with "helper" function. The consequence of HIV replication in CD4+ T cells is their depletion in association with a profound cytopathic effect, including formation of large syncytia in vitro. In vivo, HIV infection of CD4+ T cells leads to their progressive depletion leading to a state of profound immunodeficiency known as acquired immunodeficiency syndrome (AIDS) with emergence of opportunistic infections and peculiar types of cancer resulting in the death in $>95 \%$ of infected individuals if combination antiretroviral therapy (cART) is not administered [2, 3]. Conversely, HIV infection of tissue macrophages neither causes their depletion in vitro nor in vivo, perhaps reflecting the coevolution between lentiviruses and myeloid cells.

HIV infection of macrophages has been largely studied in vitro upon differentiation of human peripheral blood monocytes into differentiated cells (i.e., monocyte-derived macrophages, MDM). Although MDM have been largely interpreted as a surrogate model of the physiological differentiation pathway of myeloid cells, it has been recently demonstrated that it actually represents only an "emergence" pathway of cell recruitment into inflamed tissues. Indeed, most tissue-resident macrophages (TRM) derive from primordial embryonic structures and seed the peripheral tissues before the development of the vessels, blood and bone marrow [4,5]. TRM play a role in tissues and organs as scavenger cells removing apoptotic bodies and maintain themselves through the release of cytokines inducing their homeostatic 
slow turnover [4, 5]. However, in the case of infection or inflammation, circulating monocytes are recruited in the damaged tissue through in response to chemokines and other chemotactic factors released by the site of infection and rapidly differentiate into MDM, therefore mixing with TRM in the orchestration of the local inflammatory, antimicrobial response.

There is robust evidence that TRM are targets of HIV infection in vivo, as highlighted particularly in the central nervous system (CNS) in which microglia, upon infection in the absence of cART, drives the development of a deadly encephalitis associated with a clinical condition known as AIDS-associated dementia [6]. HIV infection of macrophages has been shown also in other tissues and organs, as reviewed in [7-9] and reproduced in relevant animal models such as non-human primates (NHP) experimentally infected with the simian immunodeficiency virus (SIV) [10] and immunodeficient mice reconstituted with human progenitor cells before HIV infection [11].

Thus, with the caveat that in vitro infection of MDM might not reflect accurately all features of TRM, some of the main similarities and differences between CD4+ T cell and MDM infection can be summarized as in Table 1.

Table 1. Similarities and differences between CD4+ $\mathrm{T}$ cell and MDM infection in vitro and in vivo

\begin{tabular}{|c|c|c|c|c|}
\hline & CD4+ T cells & Macrophages & Refs. & Notes \\
\hline Entry receptors & CD4, CCR5, CXCR4 & CD4, CCR5, CXCR4 & [2] & $\begin{array}{l}\text { Although macrophages express } \\
\text { CXCR4 productive infection is } \\
\text { usually associated with CCR } 5 \text { use }\end{array}$ \\
\hline Cell proliferation & Yes & No & {$[12,13]$} & \\
\hline $\begin{array}{l}\text { Cytopathic effect, cell } \\
\text { depletion in vitro }\end{array}$ & Yes & No & [9] & \\
\hline $\begin{array}{l}\text { Cytopathic effect, cell } \\
\text { depletion in vivo }\end{array}$ & Yes & No & {$[2,9]$} & $\begin{array}{l}\mathrm{CD} 4 \mathrm{~T} \text { cell depletion in vivo is likely } \\
\text { the result of different processes } \\
\text { and not only of direct virus- } \\
\text { induced cytopathicity }\end{array}$ \\
\hline $\begin{array}{l}\text { Main pathogenetic } \\
\text { consequence }\end{array}$ & $\begin{array}{l}\text { Profound } \\
\text { immunodeficiency, } \\
\text { opportunistic infections, } \\
\text { cancer }\end{array}$ & $\begin{array}{l}\text { Tissue pathology, } \\
\text { brain infection } \\
\text { (encephalitis) }\end{array}$ & {$[2,14]$} & \\
\hline $\begin{array}{l}\text { Virus budding and } \\
\text { release }\end{array}$ & Plasma membrane only & $\begin{array}{l}\text { Plasma membrane and } \\
\text { virus containing } \\
\text { compartments (VCC) }\end{array}$ & {$[15,16]$} & $\begin{array}{l}\text { VCC have been defined as } \\
\text { invaginations of the plasma } \\
\text { membrane that can be connected } \\
\text { or not with the cell surface }\end{array}$ \\
\hline $\begin{array}{l}\text { Role as viral reservoirs } \\
\text { in cART-treated } \\
\text { individuals }\end{array}$ & $\begin{array}{l}\text { Well-demonstrated in the } \\
\text { case of latently infected } \\
\text { "resting memory" cells }\end{array}$ & $\begin{array}{l}\text { Strong evidence in } \\
\text { support of TRM }\end{array}$ & {$[17-21]$} & $\begin{array}{l}\text { TRM are credited with a longer } 1 / 2 \\
\text { life than MDM }\end{array}$ \\
\hline
\end{tabular}

\section{Host cell restriction factors, HIV infection and replication}

There is abundant evidence of a complex network of intracellular factors already expressed in many cell types in the absence of an infection thereby providing a state of "intrinsic immunity" [22]. A general feature is their upregulation by interferons (IFNs) that are generated in response to viral infection or vaccination. In the case of HIV, the first clearcut evidence of "intrinsic immunity" came by studying cell lines with either "permissive" or "nonpermissive" 
phenotypes in terms of virus infection and replication. Permissive cell lines were demonstrated to be devoid of an intracellular gatekeeper belonging to the apolipoprotein B mRNA-editing catalytic polypeptide (APOBEC) family [23], namely APOBEC3G (A3G), a cytidine deaminase targeted to proteasomal degradation by the virion-associated accessory protein Vif. In the case of viruses lacking Vif expression, A3G present in host cells interferes with the process of reverse transcription of the genomic viral RNA into DNA by converting the cytosines present in the minus strand into uracils thereby resulting in accumulation of G-to-A mutations in the plus strand. This seminal discovery inspired the paradigm that restriction factors such as A3G are often counteracted by specific viral genes consequent to a long coevolution process [24]. After A3G, other members of the APOBEC family have shown similar anti-HIV activity, with particular regard to $\mathbf{A} 3 \mathbf{C}, \mathbf{A} 3 \mathbf{D}, \mathbf{A} 3 \mathbf{F}$ and $\mathbf{A} 3 \mathbf{H}$, as reviewed in [25]. Like A3G also A3F and A3H (but not other members) are inhibited by Vif [24].

In the case of HIV, and of retroviruses in general, the goal of restriction factors is best achieved when acting before integration of proviral DNA into host cell chromosomes in order to curtail the number of persistently infected cells unaffected by cART that contribute to the establishment of the so-called "viral reservoir", nowadays a major obstacle in HIV eradication. Once proviral integration has occurred, however, certain transcription factors could be also considered operationally as "restriction factors" by favoring latent vs. productive infection, as later discussed. Finally, additional restriction factors have been shown to target late steps in the viral life cycle, therefore affecting virus spreading to target cells, as in the case of BST-2/Tetherin and SERINC5, as later discussed.

An overall list of the main HIV restriction factors relevant to HIV infection of macrophages and their main mechanism of action (when identified) is summarized in Table 2 and visualized in Figure 1.

Table 2. Main Restriction and Transcription Factors Curtailing HIV Infection or Replication in Human Macrophages

\begin{tabular}{|c|c|c|c|c|c|}
\hline $\begin{array}{l}\text { Restriction } \\
\text { Factor }\end{array}$ & $\begin{array}{l}\text { HIV Life Cycle } \\
\text { Step Affected }\end{array}$ & $\begin{array}{l}\text { Mechanism of } \\
\text { Action }\end{array}$ & $\begin{array}{l}\text { Counteracting } \\
\text { Viral Protein }\end{array}$ & Key refs & Notes \\
\hline STING, IRF3 & Viral entry & $\begin{array}{l}\text { Low levels IFN } \\
\text { response }\end{array}$ & $\mathrm{VpR}, \mathrm{VpX}$ & [26-28] & \\
\hline REAF & $\begin{array}{l}\text { Early post-entry } \\
\text { events }\end{array}$ & Unclear/unknown & VpR & [29] & \\
\hline TRIM5 $\alpha$ & $\begin{array}{l}\text { Early post-entry } \\
\text { events }\end{array}$ & $\begin{array}{l}\text { Degradation of } \\
\text { incoming viral } \\
\text { capsid }\end{array}$ & & {$[24,30]$} & $\begin{array}{l}\text { Human TRIM5 } \alpha \text { prevents animal } \\
\text { lentivirus infection, but not HIV }\end{array}$ \\
\hline $\begin{array}{l}\text { APOBEC-3 } \\
\text { members }\end{array}$ & $\begin{array}{l}\text { Reverse } \\
\text { transcription }\end{array}$ & $\begin{array}{l}\mathrm{C} \text { to } \mathrm{A} \\
\text { hypermutation }\end{array}$ & Vif & {$[24,31]$} & \\
\hline Tet2 & $\begin{array}{l}\text { Reverse } \\
\text { transcription }\end{array}$ & $\begin{array}{l}\text { Cytosine } \\
\text { demethylation }\end{array}$ & VpR & [32] & \\
\hline SAMHD1 & $\begin{array}{l}\text { Reverse } \\
\text { transcription }\end{array}$ & $\begin{array}{l}\text { Depletion of dNTP } \\
\text { pool }\end{array}$ & VpX (HIV-2) & [9] & $\begin{array}{l}\text { SAMHD1 is involved in the } \\
\text { Aicardi Goutières Syndrome }\end{array}$ \\
\hline $\mathrm{MxB}$ & $\begin{array}{l}\text { Reverse } \\
\text { transcription }\end{array}$ & $\begin{array}{l}\text { Interaction with } \\
\text { PIC }\end{array}$ & & {$[33-35]$} & PIC: Pre-Integration Complex \\
\hline TREX-1 & $\begin{array}{l}\text { Complex with } \\
\text { HIV DNA }\end{array}$ & $\begin{array}{l}\text { prevention of IFN } \\
\text { induction }\end{array}$ & & {$[36,37]$} & $\begin{array}{l}\text { TREX1 is involved in the Aicardi } \\
\text { Goutières Syndrome }\end{array}$ \\
\hline TRIM22 & $\begin{array}{l}\text { Integrated } \\
\text { provirus }\end{array}$ & $\begin{array}{l}\text { Transcriptional } \\
\text { repression }\end{array}$ & & [38] & \\
\hline
\end{tabular}




\begin{tabular}{|c|c|c|c|c|c|}
\hline $\begin{array}{l}\text { NF-kB1 } \quad(p 50) \\
\text { homodimers }\end{array}$ & $\begin{array}{l}\text { Integrated } \\
\text { provirus }\end{array}$ & $\begin{array}{l}\text { Transcriptional } \\
\text { repression }\end{array}$ & & {$[39,40]$} & $\begin{array}{l}\text { Active NF-kB is composed of a } \\
\text { heterodimer of p50 and p75 }\end{array}$ \\
\hline p21/Waf1 & $\begin{array}{l}\text { Integrated } \\
\text { provirus }\end{array}$ & $\begin{array}{l}\text { Transcriptional } \\
\text { repression }\end{array}$ & & {$[41,42]$} & \\
\hline CIITA & $\begin{array}{l}\text { Integrated } \\
\text { provirus }\end{array}$ & $\begin{array}{l}\text { Transcriptional } \\
\text { repression }\end{array}$ & & {$[43,44]$} & $\begin{array}{l}\text { CIITA also repressed HTLV-1/2 } \\
\text { Tax transcriptional activity }\end{array}$ \\
\hline BST-2/ Tetherin & $\begin{array}{l}\text { Budding and } \\
\text { virion release }\end{array}$ & $\begin{array}{l}\text { Prevention of } \\
\text { virion release from } \\
\text { plasma membrane }\end{array}$ & $\mathrm{VpU}\left(\mathrm{Nef}^{* *}\right)$ & {$[31,45,46]$} & \\
\hline IFITM1, 2, 3 & $\begin{array}{l}\text { Budding and } \\
\text { virion release }\end{array}$ & $\begin{array}{l}\text { Incorporation into } \\
\text { nascent HIV-1 } \\
\text { virions }\end{array}$ & VpR & [47] & \\
\hline $\begin{array}{l}\text { Mannose } \\
\text { Receptor }\end{array}$ & $\begin{array}{l}\text { Budding and } \\
\text { virion release }\end{array}$ & $\begin{array}{l}\text { Envelope } \\
\text { incorporation into } \\
\text { virions }\end{array}$ & VpR, Nef & {$[48,49]$} & \\
\hline GBP-5 & $\begin{array}{l}\text { Budding and } \\
\text { virion release }\end{array}$ & & VpU & [50] & \\
\hline $\begin{array}{l}\text { MARCH1, } 2 \text { and } \\
8\end{array}$ & $\begin{array}{l}\text { Budding and } \\
\text { virion release }\end{array}$ & $\begin{array}{l}\text { Envelope } \\
\text { incorporation into } \\
\text { virions }\end{array}$ & & {$[51,52]$} & \\
\hline SERINC5 & $\begin{array}{l}\text { Budding and } \\
\text { virion release }\end{array}$ & $\begin{array}{l}\text { Prevention of cell } \\
\text { fusion }\end{array}$ & Nef & {$[53,54]$} & \\
\hline $\begin{array}{l}\text { Cholesterol 25- } \\
\text { hydroxylase }\end{array}$ & $\begin{array}{l}\text { Budding and } \\
\text { virion release }\end{array}$ & $\begin{array}{l}\text { Prevention of cell } \\
\text { fusion }\end{array}$ & & [55] & \\
\hline
\end{tabular}




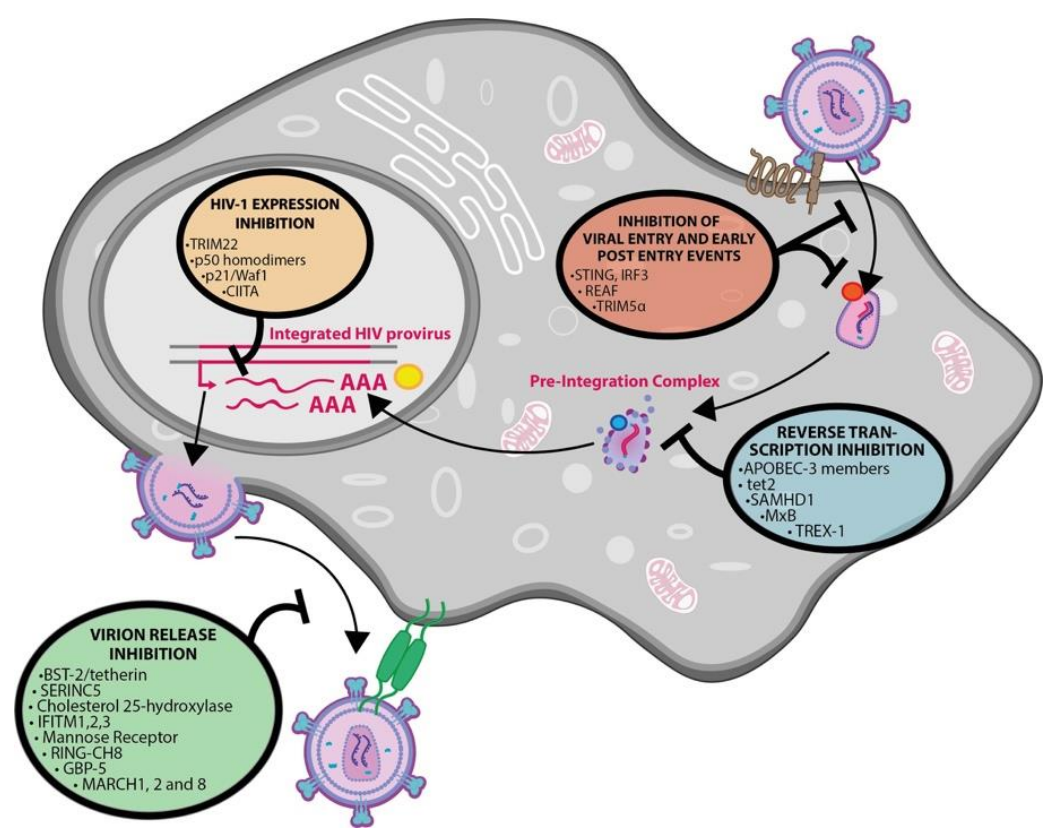

Figure 1. Restriction and transcription factors acting on HIV-1 infection in myeloid cells. See Table 2 for details.

\section{Restriction factors and counteracting viral proteins active in myeloid cells}

Among other accessory genes encoded by HIV, VpR, a virion-associated protein, has been early characterized as a relevant factor to allow efficient virus replication in macrophages $[56,57]$. Its mechanism(s) of action has/have been debated for several years and likely does not rely on a single modality. Experimental evidence supports an active role of $\mathrm{VpR}$ as transcriptional booster of provirus expression potentially involving its interaction with the intracellular glucocorticoid receptor [58] followed by its translocation from cytoplasm into the cell nucleus and leading to cell cycle arrest in $\mathrm{G}_{2} / \mathrm{M}$ phase [59-61]. The importance of VpR in HIV pathogenesis is supported by in vivo studies in NHP [62] and in HIV-1+ long-term nonprogressors (LTNP) infected with VpR-defective viruses [63] as well as by a rare case of human infection in a laboratory setting [64], as discussed in detail in [26]. It has been suggested that VpR could cooperate with Vif in the interaction with A3G leading to its proteasomal degradation [65].

In addition to A3G, other members of the APOBEC family have shown restrictive effects on HIV-1 infection. Although A3A was not initially included among those, we [66] and others [67,68] have collected evidence of its potential role as restriction factor for HIV-1 infection in monocytes and macrophages, as later discussed. Of interest, an IFNindependent regulation of A3A expression has been observed in association with the downregulation of endogenously released chemokine CCL2/MCP-1 [69]. In the same study, CCL2 downregulation led to NF-KB mediated upregulation of the microRNA miR-155 that modulates the expression of several genes, including chemokines and their receptors [69].

Another target of $\mathrm{VpR}$ potentially relevant for HIV infection of macrophages is Tet2 (ten eleven translocation 2), a member of the family of DNA dioxygenase that leads to cytosine demethylation [70]. Vpr-dependent degradation of Tet2 has been associated with an increased secretion of interleukin-6 (IL-6) by HIV-infected macrophages enhancing virus replication by acting in an autocrine/paracrine fashion [71]. In addition, Tet2 upregulates the expression of iFNinduced transmembrane protein 3 (IFITM3), restricting virus replication in cooperation with IFTIM2 [32]. Finally, VpR has been shown to interfere with the transcription of type 1 IFNs [72, 73] as well as with the recently described RNAassociated Early-Stage Antiviral Factor (REAF) acting on early steps of the virus life cycle both in cell lines [74] and in primary human MDM [29].

As mentioned above, a peculiar property of macrophages is their long survival in culture in a nonproliferating state [although tissue-resident macrophages undergo a slow homeostatic proliferation driven by cytokines secreted in 
an autocrine fashion in order to persist indefinitely in the host $[4,5]]$ caused by a physiological arrest of their cell cycle. This aspect of their biology has been recently revisited for its relevance to HIV infection and the role of restriction factors, with particular regard to SAMHD1 (SAM domain and HD domain-containing protein 1), a hydrolase processing deoxynucleotides triphosphates (dNTPs) physiologically involved in DNA repair mechanisms [13]. SAMHD1 acts by depleting the pool of dNTPs that are the "building blocks" necessary to the reverse transcription process in order to synthesize viral DNA before its integration into the host cell genome. Vpx is an accessory protein of the HIV-2, but not of the HIV-1 genome, that targets SAMHD1 for proteasomal degradation thus allowing efficient virus replication [75, 76]. As HIV-1 is devoid of Vpx it has been highly debated whether a similar mechanism of SAMHD1 inactivation would be expressed by other accessory viral proteins. in this regard, Ferreira and colleagues have reported that, although in the absence of cell division [13], macrophages in Go phase express p21/Waf1, previously shown to represent a negative regulator of virus replication in macrophages [41], together with high levels of SAMHD1 thereby resulting in a highly restricted state in terms of virus replication. Their switch to $G_{1}$ has been associated with downregulation of p21/Waf1, increased expression of cyclin dependent kinase 1 (CDK1) and inactivation of SAMHD1 by means of its phosphorylation leading to increased levels of dNTPs and unleashing of virus replication. This pathway was reverted by conditions such as genotoxic stress and response to "danger signals" that favored a back-transition from $\mathrm{G}_{1}$ to $\mathrm{G}_{0}$, as reviewed in [13].

The IFN-inducible human myxovirus resistance protein B (MxB), related, but distinct from MxA, has been recently described as restriction factor for HIV-1 infection by acting after the completion of the reverse transcription process but before proviral integration likely trough interaction with capsid-cyclophilin A [77-80].

A well-described feature of HIV-1 replication in macrophages is the lack of induction of a robust type 1 IFN response upon infection, likely explained by the activity of the TREX1 exonuclease [81, 82], although a modest induction of IFN induced genes (ISG) can be observed upon infection [83, 84]. In the absence of a specific cytosolic sensor, it has been hypothesized that the perturbation of the plasma membrane caused by the interaction with HIV-1 virions would be sufficient to trigger a canonical activation of a STimulator of INterferon Genes (STING)-dependent pathway involving the IFN-responsive factor 3 (IRF-3) $[85,86]$. In addition, a second wave of ISG expression has been reported to occur a few days after infection following proviral integration and synthesis of the viral regulatory protein Tat, as reviewed in [51].

Once integrated as proviral DNA, the expression of the HIV genome falls under the control of both viral and host factors influencing its transcription, RNA splicing and export from the nucleus to the cytoplasm, translation into viral proteins and their assembly with full-length viral RNA at the plasma membrane to generate new progeny virions. The role of negative regulators of proviral transcription (described in Table 2) will be discussed later.

The last steps of the viral life cycle, namely the budding and release of new virions, is a target of modulation by several RF, as earlier described in the case of Tetherin/BST-2, an IFN-inducible tetraspanin that keeps the virions stuck at the cell surface and not released; its action is counteracted by the viral accessory protein $\mathbf{V p u}$ that promotes its degradation $[87,88]$. In addition to IFN, also the presence of the viral accessory protein Nef has been associated with increasing levels of Tetherin expression in macrophages [89]. In addition, proteins of the IFITM family (in particular, IFITM1, 2 and 3) interfere with the release of new virions by inserting themselves into the Env of nascent virions thereby impairing cell fusion in models of cell-to-cell viral spreading [90, 91]. Of note is the fact that their restriction seems particularly effective in macrophages [92]. Furthermore, two recently identified restriction factors (membraneassociated RING-CH 8 (MARCH8) and guanylate binding protein-5, GBP-5 (this latter counteracted by the viral accessory protein $\mathbf{V p u}$ ) expressed in macrophage target HIV-1 gp120 Env, therefore playing a role in the final phases of budding and release of new progeny virions [50,52]. Members of the MARCH family of E3-ubiquitin ligases are under the control of IFN and were previously shown to downregulate several host cell proteins from the plasma membrane and limiting the levels of HIV-1 Env incorporation into budding virions therefore resulting in their decreased infectivity. In particular, MARCH8 is endogenously expressed by MDM and dendritic cells whereas its KO results in a 
significant boost of virion infectivity [52]. Similarly, MARCH1 and MARCH2 likely interfere with Env incorporation into virions [93], as reviewed in [51].

SERINC3 and SERINC5 are host molecule that significantly decreases virion infectivity by interfering with the fusogenic properties of HIV-1 Env glycoproteins whereas the accessory viral protein Nef prevents their incorporation into nascent virions at the plasma membrane [53,54]. Their effect has been mostly studied in cell lines, but although they seem to be dispensable for virus replication in primary activated CD4+ T cells, recent studies have described its relevance particularly for primary macrophages, although with significant inter-donor variability [94]. Of interest, SERINC5 expression is upregulated during differentiation of monocytes into MDM [95] and its incorporation into virions has been linked to the upregulated production of pro-inflammatory cytokines, including tumor necrosis factor$\alpha$ (TNF- $\alpha$ ), IL-6 and others, an effect that was also prevented by Nef [94]. SerinC5-induced release of pro-inflammatory cytokines by MDM occurred in synergy with the CCR5 antagonist Maraviroc that blocks virions bound to CD4 on the plasma membrane [96]. In this regard, SERINC5-expressing virions showed a greater susceptibility to inhibition by either Maraviroc or neutralizing antibodies [97]. Thus, in addition to its direct antiviral effect, SERINC5 incorporation into virions may serve as "danger signal" to the infected cells to trigger or enhance a pro-inflammatory response finalized to counteract the infection.

A restriction factor lately emerged as capable of influencing the capacity of HIV to infect cells is the IFN-inducible cholesterol 25-hydroxylase that produced oxysterols, mediators of several process including inflammation and immune activation $[98,99]$. In addition to HIV, this ER-associated enzyme can limit the infectivity of several enveloped viruses, including Ebola, Influenza A viruses and poliovirus, an RNA virus lacking the envelope. Overall, oxysterols are believed to restrict infection at the levels of viral entry by interfering with the fusion of the virion-target cell membranes, a reviewed in [55].

The mannose receptor (MR) expressed by macrophages plays a fundamental role as extracellular sensor of bacterial and fungal invasion promoting their phagocytosis. Bacterial countermeasures include the synthesis of lipoarabinomannan by Mycobacterium tuberculosis that binds and downregulated the MR leading to the inhibition of a protective inflammatory response, as reviewed in [100]. In addition, MR can serve as entry receptor for Dengue virus and can also interact with HIV-1 virions like other cell surface molecules including DC-SIGN [101] and the integrin $\alpha 4 \beta 7$ [102]. Interaction of HIV virions with the MR may facilitate trans-infection of CD4+ T lymphocytes. Interestingly, MR is dowregulated by the HIV-1 accessory proteins VpR [48] and Nef [49]. As MR destabilizes gp120 Env expression on the MDM cell surface, VpR dual targeting of MR and IFITM3 may ultimately favor the capacity of infected MDM to spread the infection, as discussed in [100].

\section{Macrophage polarization to a pro-inflammatory mode. A model of HIV-1 restriction.}

In addition to a profound revisitation of their ontogenesis macrophage biology has been reinterpreted beyond the classical view of a cell responding to pro-inflammatory signals according to a simple "on-off" modality. A paradigm of an "M1/M2" functional polarization was generated in analogy to the well-defined Th1/Th2 established modality of diversification of CD4+ T helper cell activation. Classically activated M1 macrophages are induced by well-known proinflammatory signals, including bacterial endotoxin and cytokines such as IFN- $\gamma$ and tumor necrosis factor- $\alpha$ (TNF- $\alpha$ ) whereas M2 macrophages are considered "alternatively activated" by anti-inflammatory and immunoregulatory signals including IL-4, IL-10 and others. M1 macrophages contribute to the inflammatory process and, in general, exert anti-microbial and anti-cancer effects, whereas M2 macrophage polarization exerts anti-inflammatory effects together with tissue-regenerating activities, including neoangiogenesis, for which it is usually considered as cells favoring cancer growth and exerting variable effects in terms of antimicrobial activities, as reviewed in (ref). Of note is the fact that, unlike Th1/Th2 lymphocytes, macrophage polarization is a transient condition with cells returning to their basal state a 
few days after the polarizing signals have been withdrawn. This dichotomous view has been tempered by considering "M1" and "M2" as the two extremes of a spectrum of functional profiles [103].

We have originally investigated the implications of M1/M2 polarization for HIV-1 infection of primary human MDM). In order to distinguish cell polarization from the direct effect of the polarizing cytokines on HIV-1 infection, differentiated MDM were preincubated for $18 \mathrm{~h}$ with IFN- $\gamma$ and TNF- $\alpha$ or with IL-4, in order to induce M1 or M2 polarization, respectively, and the cytokines were then removed before infection. Quite unexpectedly, we observed that both M1 and M2 polarization led to reduced levels of virus replication, although with different profiles. M1-MDM showed a more robust inhibition of virus replication (ca. 90\% vs. control, unpolarized cells) whereas M2-MDM decreased HIV-1 production by ca. 50\% although M2-induced inhibition of virus production lasted longer than that caused by M1 signals that vanished ca. 3 days after removal of the cytokines [104]. M1 polarization was associated with a profound downregulation of CD4 from the plasma membrane together with an upregulated secretion of some CCR5binding chemokines. Therefore, we initially proposed that M1 polarization induced a potent, yet partial restriction of viral entry, as supported by the quantitative analysis of cell-associated HIV DNA [104]. Concerning M2-MDM we further demonstrated a significant role of DC-SIGN in the restricted patters observed [101].

We then investigated whether the M1 restriction could be also observed bypassing the cell entry step using a VSVg pseudotyped virus. The results indicated that also this virus was profoundly restricted in its capacity to replicate in human MDM [66], suggesting a model whereby M1 polarization imposes different "hurdles" to virus replication both at the levels of viral entry and at one or more post-entry steps [104]. Of note, we observed a clear-cut upregulation of APOBEC-3A (A3A) in M1, but not in M2, MDM that returned to the levels observed in monocytes [66]. This observation, together independent reports from other research groups [67], suggested that A3A could be involved in the overall restricted profile of HIV-1 replication typical of M1-MDM. No significant modulation of A3G or SAMHD1 was observed in polarized vs. unpolarized macrophages.

These initial studies were finalized to explore whether M1/M2 polarization of macrophages before infection would affect their susceptibility to support virus replication in case of infection. Therefore, we next investigated the potential role of functional macrophage polarization in already infected cells; based on the observation of a more profound inhibitory effect of M1 polarization on virus replication, these experiments were not conducted with M2-MDM. A caveat to these experiments was based on the very well-known effects of both IFN- $\gamma$ and, particularly, TNF- $\alpha$ on virus replication as a consequence of their activation of transcription factors acting on integrated proviruses by promoting or enhancing their transcription. In this regard, both STAT1, activated by IFN- $\gamma$, and NF-kB (induced by TNF- $\alpha$ ) have welldefined binding sites in the 5'-LTR of the HIV-1 provirus. Therefore, we hypothesized that the restimulation of M1MDM with IFN- $\gamma$ and TNF- $\alpha$ several days after infection (allowing proviral integration to occur) could result in triggering virus replication as a consequence of the positive effects of STAT1 and NF-kB on those cells carrying integrated proviruses.

Quite surprisingly, we observed a very reproducible pattern whereby repolarization with M1-cytokines of HIV-1 infected M1-MDM (an experimental condition that we defined as "M12-MDM") drove virus replication to nearly undetectable levels (in the absence of cytopathic effects) (Figure 2). The levels of HIV-1 DNA remained ca. 100-fold lower than those of control, unpolarized MDM whereas they returned to levels similar to those of control cells in the case of M1-MDM that were not restimulated by M1-cytokines. Finally, both unspliced and multiply spliced HIV-1 RNA remained at baseline levels when measured 8 days post-infection (i.e., $24 \mathrm{~h}$ after cytokine restimulation). As expected, $\mathrm{A} 3 \mathrm{~A}$, and also A3G, were promptly upregulated in M12-MDM in comparison to control and M1-MDM that were not restimulated [43]. This quasi-silent pattern of HIV expression was not correlated with the lack of induction of STAT1 and NF-kB in these cells whereas other factors known to act as repressors of proviral transcription, namely TRIM22 and CIITA, were also upregulated [43]. 
TRIM22, also known as Staf50, is an ISG whose expression is profoundly upregulated by IFN stimulation of different cell types [38]. Our group described it as the key factors differentiating U937 cell clones with a restrictive phenotype in terms of supporting HIV-1 replication ("Minus clones") in comparison to those fully permissive (Plus clones) [105]. TRIM22 does not possess a DNA binding domain and acts, at least in part, by preventing the binding of Sp1, a positive transcription factor constitutively expressed by many cell types, to the core promoter of the HIV-1 provirus [106]. CIITA was originally described to be the key transcription factor for MHC Class II antigen expression under the control of IFN- $\gamma$, as reviewed [44]. It was then demonstrated to play a significant role in the inhibition of both HTLV-1/HTLV-2 transcription and by competing with the regulatory protein Tat for binding to P-Tefb (a complex formed by Cyclin $\mathrm{t} 1$ and CDK9) in order to enhance HIV-1 proviral transcription also in myeloid cells [107].

Therefore, restimulation of HIV-1 infected M1-MDM by M1 cytokines induced both positive and negative restriction factors with the latter dominating over the former (Figure 2). Therefore, M12-MDM could represent a potential model to investigate the hypothesis that, together with $\mathrm{CD} 4+\mathrm{T}$ cells, also myeloid cells including macrophages could contribute to the establishment and maintenance of the viral reservoir resistant to cART. Indeed, cocultivation of M12-MDM with allogeneic PBMC stimulated by the mitogen phytohemagglutinin (PHA) or incubation with their culture supernatants potently reverted virus infection into a productive one [43]. PHA-stimulated PBMC were not resuspended in a culture medium containing IL-2 to promote the formation of PHA blasts because M12-MDM were incubated with PHA blasts they were readily eliminated by cell killing from the cell culture and/or diluted out by the proliferating cell [43]. Reversal from a state of quasi-latency to a fully productive infection induced by PHA-stimulated PBMC or their supernatant was selectively observed in M12-MDM, but not in control or M1-MDM that had not been restimulated [43] perhaps because restimulation with M1 cytokines upregulated NF-kB and STAT1 (together with other transcription factors) that, in addition to the "kick" provided by allogeneic PHA-stimulated PBMC, tilted the balance of proviral transcription in favor of virus expression (Figure 2). These observations were confirmed after MDM infection with a VSV-g pseudotyped virus demonstrating that proviral reactivation occurred in a single HIV replicative cycle level [43].

Thus, M12-MDM represent a robust model to investigate which factors can affect either positively or negatively HIV-1 infection, latency and replication in myeloid cells. It should be underscored, in this regard, that TRM, and not CD4+ T cells, have been shown to represent the viral reservoir in urethral tissue of HIV-infected men receiving cART and undergoing gender reassortment [20], whereas the existence of M1-polarized macrophages exhibiting a restricted profile compatible with our in vitro observations has been demonstrated in vivo at least in the case of decidual macrophages [18].

A.

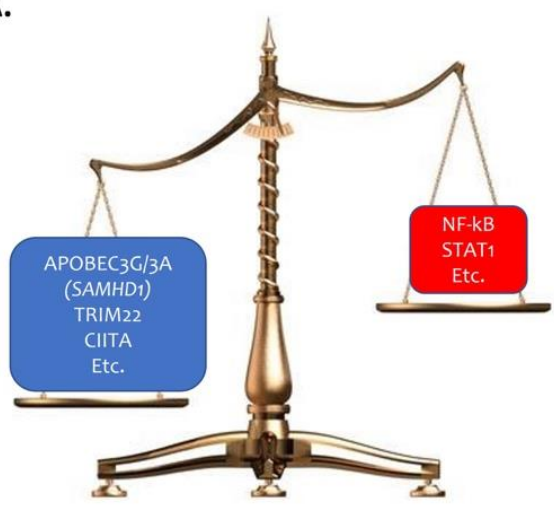

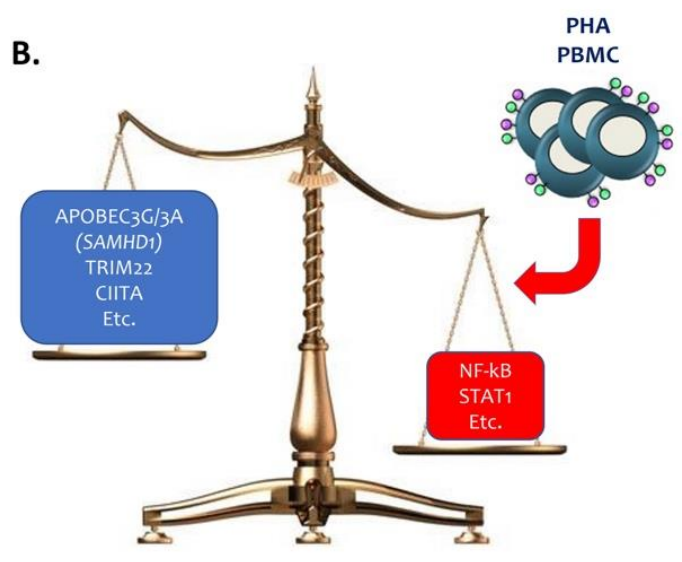

Figure 2. M12-MDM: A model of reversible HIV-1 latency in primary human MDM. A. Restimulation of infected M1MDM with M1 cyotokines (IFN- $\gamma$ and TNF- $\alpha$ ) resulted in a very restricted profile of HIV-1 infection associated with the 
expression of both negative (blue box) and positive (red box) restriction and transcription factors in terms of virus expression. B. coculture with PHA-stimulated allogeneic PBMC (in the absence of IL-2) tilted the balance of these factors resulting in a productive infection.

\section{Conclusions}

HIV-1 infection of CD4+ cells involves primarily a prominent subset of T lymphocytes and myeloid cells. These latter encompass very different cell types, such as myeloid dendritic cells, circulating monocytes, eventually extravasating to become MDM in inflammatory conditions, and TRM that acquire very distinctive features according to the anatomical site (from Kupffer cells in the liver to the microglia in the CNS). Although the prominent role of latently infected CD4+ T cells in establishing and diversifying the HIV reservoir of cells carrying replication-competent proviruses has been well established, a growing number of evidence indicates that myeloid cells could also contribute significantly to this unsolved issue preventing the eradication of HIV-1 infection from cART-treated individuals. The identification of specific extracellular and intracellular factors influencing the susceptibility of myeloid cells to become targets of either latent or productive infection could be a crucial goal in order to define effective strategies aiming at the curtailment of the HIV-1 reservoir or to its definitive silencing.

Author Contributions: GP designed the overall structure of the review; IP, SG and EV contributed to the literature analysis concerning restriction factors, PD contributed to the optimization of the M1-MDM model of HIV restriction. All authors reviewed and concurred with the hypotheses and interpretations of this article.

Funding: this article contains a description of original results funded in part by the PRIN project 2017TYTWZ3 to GP. Institutional Review Board Statement: Not applicable.

Informed Consent Statement: Not applicable..

Acknowledgments: the authors wish to thank previous collaborators on the characterization of TRIM22 restriction factor, and particularly Dr. Anna Kajaste-Rudnitski, and on the optimization of the M1-MDM model of HIV-1 restriction, and particularly Dr. Francesca Graziano.

Conflicts of Interest: the authors declare no conflict of interest.

\section{References}

1. de Pablo-Maiso, L.; Domenech, A.; Echeverria, I.; Gomez-Arrebola, C.; de Andres, D.; Rosati, S.; Gomez-Lucia, E.; Reina, R., Prospects in Innate Immune Responses as Potential Control Strategies against Non-Primate Lentiviruses. Viruses 2018, 10, (8).

2. International, A. S. S. W. G. o. H. I. V. C.; Deeks, S. G.; Autran, B.; Berkhout, B.; Benkirane, M.; Cairns, S.; Chomont, N.; Chun, T. W.; Churchill, M.; Di Mascio, M.; Katlama, C.; Lafeuillade, A.; Landay, A.; Lederman, M.; Lewin, S. R.; Maldarelli, F.; Margolis, D.; Markowitz, M.; Martinez-Picado, J.; Mullins, J. I.; Mellors, J.; Moreno, S.; O'Doherty, U.; Palmer, S.; Penicaud, M. C.; Peterlin, M.; Poli, G.; Routy, J. P.; Rouzioux, C.; Silvestri, G.; Stevenson, M.; Telenti, A.; Van Lint, C.; Verdin, E.; Woolfrey, A.; Zaia, J.; Barre-Sinoussi, F., Towards an HIV cure: a global scientific strategy. Nat Rev Immunol 2012, 12, (8), 607-14.

3. Cohn, L. B.; Chomont, N.; Deeks, S. G., The Biology of the HIV-1 Latent Reservoir and Implications for Cure Strategies. Cell Host Microbe 2020, 27, (4), 519-530.

4. Perdiguero, E. G.; Geissmann, F., The development and maintenance of resident macrophages. Nat Immunol 2016, 17, (1), 2-8. 
5. Hoeffel, G.; Ginhoux, F., Fetal monocytes and the origins of tissue-resident macrophages. Cell Immunol 2018, 330, 5-15.

6. Brew, B. J.; Barnes, S. L., The impact of HIV central nervous system persistence on pathogenesis. AIDS 2019, 33 Suppl 2, S113-S121.

7. Wong, M. E.; Jaworowski, A.; Hearps, A. C., The HIV Reservoir in Monocytes and Macrophages. Front Immunol 2019, 10, 1435.

8. Wong, M. E.; Jaworowski, A.; Hearps, A. C., Corrigendum: The HIV Reservoir in Monocytes and Macrophages. Front Immunol 2019, 10, 2517.

9. Hendricks, C. M.; Cordeiro, T.; Gomes, A. P.; Stevenson, M., The Interplay of HIV-1 and Macrophages in Viral Persistence. Front Microbiol 2021, 12, 646447.

10. Beck, S. E.; Queen, S. E.; Metcalf Pate, K. A.; Mangus, L. M.; Abreu, C. M.; Gama, L.; Witwer, K. W.; Adams, R. J.; Zink, M. C.; Clements, J. E.; Mankowski, J. L., An SIV/macaque model targeted to study HIV-associated neurocognitive disorders. J Neurovirol 2018, 24, (2), 204-212.

11. Honeycutt, J. B.; Thayer, W. O.; Baker, C. E.; Ribeiro, R. M.; Lada, S. M.; Cao, Y.; Cleary, R. A.; Hudgens, M. G.; Richman, D. D.; Garcia, J. V., HIV persistence in tissue macrophages of humanized myeloid-only mice during antiretroviral therapy. Nat Med 2017, 23, (5), 638-643.

12. Hume, D. A.; Summers, K. M.; Rehli, M., Transcriptional Regulation and Macrophage Differentiation. Microbiol Spectr 2016, 4, (3).

13. Ferreira, I.; Porterfield, J. Z.; Gupta, R. K.; Mlcochova, P., Cell Cycle Regulation in Macrophages and Susceptibility to HIV-1. Viruses 2020, 12, (8).

14. Chen, Z.; Zhong, D.; Li, G., The role of microglia in viral encephalitis: a review. J Neuroinflammation 2019, 16, (1), 76 .

15. Tan, J.; Sattentau, Q. J., The HIV-1-containing macrophage compartment: a perfect cellular niche? Trends Microbiol 2013, 21, (8), 405-12.

16. Graziano, F.; Vicenzi, E.; Poli, G., The ATP/P2X7 axis in human immunodeficiency virus infection of macrophages. Curr Opin Pharmacol 2019, 47, 46-52.

17. Costiniuk, C. T.; Jenabian, M. A., The lungs as anatomical reservoirs of HIV infection. Rev Med Virol 2014, 24, (1), 35-54.

18. El Costa, H.; Quillay, H.; Marlin, R.; Cannou, C.; Duriez, M.; Benjelloun, F.; de Truchis, C.; Rahmati, M.; Ighil, J.; Barre-Sinoussi, F.; Nugeyre, M. T.; Menu, E., The local environment orchestrates mucosal decidual macrophage differentiation and substantially inhibits HIV-1 replication. Mucosal Immunol 2016, 9, (3), 634-46.

19. Lamers, S. L.; Rose, R.; Maidji, E.; Agsalda-Garcia, M.; Nolan, D. J.; Fogel, G. B.; Salemi, M.; Garcia, D. L.; Bracci, P.; Yong, W.; Commins, D.; Said, J.; Khanlou, N.; Hinkin, C. H.; Sueiras, M. V.; Mathisen, G.; Donovan, S.; Shiramizu, B.; Stoddart, C. A.; McGrath, M. S.; Singer, E. J., HIV DNA Is Frequently Present within Pathologic Tissues Evaluated at Autopsy from Combined Antiretroviral Therapy-Treated Patients with Undetectable Viral Loads. J Virol 2016, 90, (20), 8968-83.

20. Ganor, Y.; Real, F.; Sennepin, A.; Dutertre, C. A.; Prevedel, L.; Xu, L.; Tudor, D.; Charmeteau, B.; CouedelCourteille, A.; Marion, S.; Zenak, A. R.; Jourdain, J. P.; Zhou, Z.; Schmitt, A.; Capron, C.; Eugenin, E. A.; Cheynier, R.; Revol, M.; Cristofari, S.; Hosmalin, A.; Bomsel, M., HIV-1 reservoirs in urethral macrophages of patients under suppressive antiretroviral therapy. Nat Microbiol 2019, 4, (4), 633-644.

21. Veenhuis, R. T.; Abreu, C. M.; Shirk, E. N.; Gama, L.; Clements, J. E., HIV replication and latency in monocytes and macrophages. Semin Immunol 2021, 101472. 
22. Chintala, K.; Mohareer, K.; Banerjee, S., Dodging the Host Interferon-Stimulated Gene Mediated Innate Immunity by HIV-1: A Brief Update on Intrinsic Mechanisms and Counter-Mechanisms. Front Immunol 2021, $12,716927$.

23. Sheehy, A. M.; Gaddis, N. C.; Choi, J. D.; Malim, M. H., Isolation of a human gene that inhibits HIV-1 infection and is suppressed by the viral Vif protein. Nature 2002, 418, (6898), 646-50.

24. Malim, M. H.; Bieniasz, P. D., HIV Restriction Factors and Mechanisms of Evasion. Cold Spring Harb Perspect Med 2012, 2, (5), a006940.

25. Azimi, F. C.; Lee, J. E., Structural perspectives on HIV-1 Vif and APOBEC3 restriction factor interactions. Protein Sci 2020, 29, (2), 391-406.

26. Fabryova, H.; Strebel, K., Vpr and Its Cellular Interaction Partners: R We There Yet? Cells 2019, 8, (11).

27. Trotard, M.; Tsopoulidis, N.; Tibroni, N.; Willemsen, J.; Binder, M.; Ruggieri, A.; Fackler, O. T., Sensing of HIV-1 Infection in Tzm-bl Cells with Reconstituted Expression of STING. J Virol 2016, 90, (4), $2064-76$.

28. Su, J.; Rui, Y.; Lou, M.; Yin, L.; Xiong, H.; Zhou, Z.; Shen, S.; Chen, T.; Zhang, Z.; Zhao, N.; Zhang, W.; Cai, Y.; Markham, R.; Zheng, S.; Xu, R.; Wei, W.; Yu, X. F., HIV-2/SIV Vpx targets a novel functional domain of STING to selectively inhibit cGAS-STING-mediated NF-kappaB signalling. Nat Microbiol 2019, 4, (12), $2552-2564$.

29. Gibbons, J. M.; Marno, K. M.; Pike, R.; Lee, W. J.; Jones, C. E.; Ogunkolade, B. W.; Pardieu, C.; Bryan, A.; Fu, R. M.; Warnes, G.; Rowley, P. A.; Sloan, R. D.; McKnight, A., HIV-1 Accessory Protein Vpr Interacts with REAF/RPRD2 To Mitigate Its Antiviral Activity. J Virol 2020, 94, (4).

30. Cloherty, A. P. M.; Rader, A. G.; Compeer, B.; Ribeiro, C. M. S., Human TRIM5alpha: Autophagy Connects Cell-Intrinsic HIV-1 Restriction and Innate Immune Sensor Functioning. Viruses 2021, 13, (2).

31. Colomer-Lluch, M.; Ruiz, A.; Moris, A.; Prado, J. G., Restriction Factors: From Intrinsic Viral Restriction to Shaping Cellular Immunity Against HIV-1. Front Immunol 2018, 9, 2876.

32. Wang, Q.; Su, L., Vpr Enhances HIV-1 Env Processing and Virion Infectivity in Macrophages by Modulating TET2-Dependent IFITM3 Expression. mBio 2019, 10, (4).

33. Betancor, G.; Jimenez-Guardeno, J. M.; Lynham, S.; Antrobus, R.; Khan, H.; Sobala, A.; Dicks, M. D. J.; Malim, M. H., Author Correction: MX2-mediated innate immunity against HIV-1 is regulated by serine phosphorylation. Nat Microbiol 2021, 6, (9), 1211.

34. Betancor, G.; Jimenez-Guardeno, J. M.; Lynham, S.; Antrobus, R.; Khan, H.; Sobala, A.; Dicks, M. D. J.; Malim, M. H., MX2-mediated innate immunity against HIV-1 is regulated by serine phosphorylation. Nat Microbiol 2021, 6, (8), 1031-1042.

35. Chai, K.; Wang, Z.; Pan, Q.; Tan, J.; Qiao, W.; Liang, C., Effect of Different Nuclear Localization Signals on the Subcellular Localization and Anti-HIV-1 Function of the MxB Protein. Front Microbiol 2021, $12,675201$.

36. Wheeler, L. A.; Trifonova, R. T.; Vrbanac, V.; Barteneva, N. S.; Liu, X.; Bollman, B.; Onofrey, L.; Mulik, S.; Ranjbar, S.; Luster, A. D.; Tager, A. M.; Lieberman, J., TREX1 Knockdown Induces an Interferon Response to HIV that Delays Viral Infection in Humanized Mice. Cell Rep 2016, 15, (8), 1715-27.

37. Davids, B. O.; Balasubramaniam, M.; Sapp, N.; Prakash, P.; Ingram, S.; Li, M.; Craigie, R.; Hollis, T.; Pandhare, J.; Dash, C., Human Three Prime Repair Exonuclease 1 Promotes HIV-1 Integration by Preferentially Degrading Unprocessed Viral DNA. J Virol 2021, 95, (17), e0055521.

38. Pagani, I.; Poli, G.; Vicenzi, E., TRIM22. A Multitasking Antiviral Factor. Cells 2021, 10, (8).

39. Montano, M. A.; Kripke, K.; Norina, C. D.; Achacoso, P.; Herzenberg, L. A.; Roy, A. L.; Nolan, G. P., NF-kappa B homodimer binding within the HIV-1 initiator region and interactions with TFII-I. Proc Natl Acad Sci U S A 1996, 93, (22), 12376-81. 
40. Della Chiara, G.; Crotti, A.; Liboi, E.; Giacca, M.; Poli, G.; Lusic, M., Negative regulation of HIV-1 transcription by a heterodimeric NF-kappaB1/p50 and C-terminally truncated STAT5 complex. J Mol Biol 2011, 410, (5), 93343.

41. Allouch, A.; David, A.; Amie, S. M.; Lahouassa, H.; Chartier, L.; Margottin-Goguet, F.; Barre-Sinoussi, F.; Kim, B.; Saez-Cirion, A.; Pancino, G., p21-mediated RNR2 repression restricts HIV-1 replication in macrophages by inhibiting dNTP biosynthesis pathway. Proc Natl Acad Sci U S A 2013, 110, (42), E3997-4006.

42. Valle-Casuso, J. C.; Allouch, A.; David, A.; Lenzi, G. M.; Studdard, L.; Barre-Sinoussi, F.; Muller-Trutwin, M.; Kim, B.; Pancino, G.; Saez-Cirion, A., p21 Restricts HIV-1 in Monocyte-Derived Dendritic Cells through the Reduction of Deoxynucleoside Triphosphate Biosynthesis and Regulation of SAMHD1 Antiviral Activity. $J$ Virol 2017, 91, (23).

43. Graziano, F.; Aimola, G.; Forlani, G.; Turrini, F.; Accolla, R. S.; Vicenzi, E.; Poli, G., Reversible Human Immunodeficiency Virus Type-1 Latency in Primary Human Monocyte-Derived Macrophages Induced by Sustained M1 Polarization. Sci Rep 2018, 8, (1), 14249.

44. Forlani, G.; Shallak, M.; Ramia, E.; Tedeschi, A.; Accolla, R. S., Restriction factors in human retrovirus infections and the unprecedented case of CIITA as link of intrinsic and adaptive immunity against HTLV-1. Retrovirology 2019, 16, (1), 34.

45. Khan, N.; Geiger, J. D., Role of Viral Protein U (Vpu) in HIV-1 Infection and Pathogenesis. Viruses 2021, 13, (8). 46. Giese, S.; Lawrence, S. P.; Mazzon, M.; Nijmeijer, B. M.; Marsh, M., The Nef Protein of the Macrophage Tropic HIV-1 Strain AD8 Counteracts Human BST-2/Tetherin. Viruses 2020, 12, (4).

47. Compton, A. A.; Bruel, T.; Porrot, F.; Mallet, A.; Sachse, M.; Euvrard, M.; Liang, C.; Casartelli, N.; Schwartz, O., IFITM proteins incorporated into HIV-1 virions impair viral fusion and spread. Cell Host Microbe 2014, 16, (6), 736-47.

48. Lubow, J.; Virgilio, M. C.; Merlino, M.; Collins, D. R.; Mashiba, M.; Peterson, B. G.; Lukic, Z.; Painter, M. M.; Gomez-Rivera, F.; Terry, V.; Zimmerman, G.; Collins, K. L., Mannose receptor is an HIV restriction factor counteracted by Vpr in macrophages. Elife 2020, 9.

49. Vigerust, D. J.; Egan, B. S.; Shepherd, V. L., HIV-1 Nef mediates post-translational down-regulation and redistribution of the mannose receptor. J Leukoc Biol 2005, 77, (4), 522-34.

50. Krapp, C.; Hotter, D.; Gawanbacht, A.; McLaren, P. J.; Kluge, S. F.; Sturzel, C. M.; Mack, K.; Reith, E.; Engelhart, S.; Ciuffi, A.; Hornung, V.; Sauter, D.; Telenti, A.; Kirchhoff, F., Guanylate Binding Protein (GBP) 5 Is an Interferon-Inducible Inhibitor of HIV-1 Infectivity. Cell Host Microbe 2016, 19, (4), 504-14.

51. Rodrigues, V.; Ruffin, N.; San-Roman, M.; Benaroch, P., Myeloid Cell Interaction with HIV: A Complex Relationship. Front Immunol 2017, 8, 1698.

52. Tada, T.; Zhang, Y.; Koyama, T.; Tobiume, M.; Tsunetsugu-Yokota, Y.; Yamaoka, S.; Fujita, H.; Tokunaga, K., MARCH8 inhibits HIV-1 infection by reducing virion incorporation of envelope glycoproteins. Nat Med 2015, 21, (12), 1502-7.

53. Rosa, A.; Chande, A.; Ziglio, S.; De Sanctis, V.; Bertorelli, R.; Goh, S. L.; McCauley, S. M.; Nowosielska, A.; Antonarakis, S. E.; Luban, J.; Santoni, F. A.; Pizzato, M., HIV-1 Nef promotes infection by excluding SERINC5 from virion incorporation. Nature 2015, 526, (7572), 212-7.

54. Usami, Y.; Wu, Y.; Gottlinger, H. G., SERINC3 and SERINC5 restrict HIV-1 infectivity and are counteracted by Nef. Nature 2015, 526, (7572), 218-23.

55. J.M. Azevedo-Pereira, P. C., Marta Calado,; Barroca, Q. S.-C. a. P., Inhibition of HIV Replication by Host Cellular Factors. In Trends in Basic and Therapeutic Options in HIV Infection - Towards a Functional Cure, 2015. 
56. Balliet, J. W.; Kolson, D. L.; Eiger, G.; Kim, F. M.; McGann, K. A.; Srinivasan, A.; Collman, R., Distinct effects in primary macrophages and lymphocytes of the human immunodeficiency virus type 1 accessory genes vpr, vpu, and nef: mutational analysis of a primary HIV-1 isolate. Virology 1994, 200, (2), 623-31.

57. Mashiba, M.; Collins, D. R.; Terry, V. H.; Collins, K. L., Vpr overcomes macrophage-specific restriction of HIV-1 Env expression and virion production. Cell Host Microbe 2014, 16, (6), 722-35.

58. Muthumani, K.; Choo, A. Y.; Zong, W. X.; Madesh, M.; Hwang, D. S.; Premkumar, A.; Thieu, K. P.; Emmanuel, J.; Kumar, S.; Thompson, C. B.; Weiner, D. B., The HIV-1 Vpr and glucocorticoid receptor complex is a gain-of-function interaction that prevents the nuclear localization of PARP-1. Nat Cell Biol 2006, 8, (2), 1709 .

59. Jowett, J. B.; Planelles, V.; Poon, B.; Shah, N. P.; Chen, M. L.; Chen, I. S., The human immunodeficiency virus type 1 vpr gene arrests infected T cells in the G2 + M phase of the cell cycle. J Virol 1995, 69, (10), 6304-13.

60. Vodicka, M. A.; Koepp, D. M.; Silver, P. A.; Emerman, M., HIV-1 Vpr interacts with the nuclear transport pathway to promote macrophage infection. Genes Dev 1998, 12, (2), 175-85.

61. Goh, W. C.; Rogel, M. E.; Kinsey, C. M.; Michael, S. F.; Fultz, P. N.; Nowak, M. A.; Hahn, B. H.; Emerman, M., HIV-1 Vpr increases viral expression by manipulation of the cell cycle: a mechanism for selection of Vpr in vivo. Nat Med 1998, 4, (1), 65-71.

62. Lang, S. M.; Weeger, M.; Stahl-Hennig, C.; Coulibaly, C.; Hunsmann, G.; Muller, J.; Muller-Hermelink, H.; Fuchs, D.; Wachter, H.; Daniel, M. M.; et al., Importance of vpr for infection of rhesus monkeys with simian immunodeficiency virus. J Virol 1993, 67, (2), 902-12.

63. Hadi, K.; Walker, L. A.; Guha, D.; Murali, R.; Watkins, S. C.; Tarwater, P.; Srinivasan, A.; Ayyavoo, V., Human immunodeficiency virus type $1 \mathrm{Vpr}$ polymorphisms associated with progressor and nonprogressor individuals alter Vpr-associated functions. J Gen Virol 2014, 95, (Pt 3), 700-711.

64. Beaumont, T.; van Nuenen, A.; Broersen, S.; Blattner, W. A.; Lukashov, V. V.; Schuitemaker, H., Reversal of human immunodeficiency virus type 1 IIIB to a neutralization-resistant phenotype in an accidentally infected laboratory worker with a progressive clinical course. J Virol 2001, 75, (5), 2246-52.

65. Zhou, D.; Wang, Y.; Tokunaga, K.; Huang, F.; Sun, B.; Yang, R., The HIV-1 accessory protein Vpr induces the degradation of the anti-HIV-1 agent APOBEC3G through a VprBP-mediated proteasomal pathway. Virus Res 2015, 195, 25-34.

66. Cassetta, L.; Kajaste-Rudnitski, A.; Coradin, T.; Saba, E.; Della Chiara, G.; Barbagallo, M.; Graziano, F.; Alfano, M.; Cassol, E.; Vicenzi, E.; Poli, G., M1 polarization of human monocyte-derived macrophages restricts pre and postintegration steps of HIV-1 replication. AIDS 2013, 27, (12), 1847-56.

67. Peng, G.; Greenwell-Wild, T.; Nares, S.; Jin, W.; Lei, K. J.; Rangel, Z. G.; Munson, P. J.; Wahl, S. M., Myeloid differentiation and susceptibility to HIV-1 are linked to APOBEC3 expression. Blood 2007, 110, (1), 393-400.

68. Berger, G.; Durand, S.; Fargier, G.; Nguyen, X. N.; Cordeil, S.; Bouaziz, S.; Muriaux, D.; Darlix, J. L.; Cimarelli, A., APOBEC3A is a specific inhibitor of the early phases of HIV-1 infection in myeloid cells. PLoS Pathog 2011, 7, (9), e1002221.

69. Covino, D. A.; Kaczor-Urbanowicz, K. E.; Lu, J.; Chiantore, M. V.; Fiorucci, G.; Vescio, M. F.; Catapano, L.; Purificato, C.; Galluzzo, C. M.; Amici, R.; Andreotti, M.; Gauzzi, M. C.; Pellegrini, M.; Fantuzzi, L., Transcriptome Profiling of Human Monocyte-Derived Macrophages Upon CCL2 Neutralization Reveals an Association Between Activation of Innate Immune Pathways and Restriction of HIV-1 Gene Expression. Front Immunol 2020, 11, 2129.

70. An, J.; Rao, A.; Ko, M., TET family dioxygenases and DNA demethylation in stem cells and cancers. Exp Mol Med 2017, 49, (4), e323. 
71. Lv, L.; Wang, Q.; Xu, Y.; Tsao, L. C.; Nakagawa, T.; Guo, H.; Su, L.; Xiong, Y., Vpr Targets TET2 for Degradation by CRL4(VprBP) E3 Ligase to Sustain IL-6 Expression and Enhance HIV-1 Replication. Mol Cell 2018, 70, (5), 961-970 e5.

72. Doehle, B. P.; Hladik, F.; McNevin, J. P.; McElrath, M. J.; Gale, M., Jr., Human immunodeficiency virus type 1 mediates global disruption of innate antiviral signaling and immune defenses within infected cells. J Virol 2009, 83, (20), 10395-405.

73. Laguette, N.; Bregnard, C.; Hue, P.; Basbous, J.; Yatim, A.; Larroque, M.; Kirchhoff, F.; Constantinou, A.; Sobhian, B.; Benkirane, M., Premature activation of the SLX4 complex by Vpr promotes G2/M arrest and escape from innate immune sensing. Cell 2014, 156, (1-2), 134-45.

74. Marno, K. M.; Ogunkolade, B. W.; Pade, C.; Oliveira, N. M.; O'Sullivan, E.; McKnight, A., Novel restriction factor RNA-associated early-stage anti-viral factor (REAF) inhibits human and simian immunodeficiency viruses. Retrovirology 2014, 11, 3.

75. Hrecka, K.; Hao, C.; Gierszewska, M.; Swanson, S. K.; Kesik-Brodacka, M.; Srivastava, S.; Florens, L.; Washburn, M. P.; Skowronski, J., Vpx relieves inhibition of HIV-1 infection of macrophages mediated by the SAMHD1 protein. Nature 2011, 474, (7353), 658-61.

76. Laguette, N.; Sobhian, B.; Casartelli, N.; Ringeard, M.; Chable-Bessia, C.; Segeral, E.; Yatim, A.; Emiliani, S.; Schwartz, O.; Benkirane, M., SAMHD1 is the dendritic- and myeloid-cell-specific HIV-1 restriction factor counteracted by Vpx. Nature 2011, 474, (7353), 654-7.

77. Goujon, C.; Moncorge, O.; Bauby, H.; Doyle, T.; Ward, C. C.; Schaller, T.; Hue, S.; Barclay, W. S.; Schulz, R.; Malim, M. H., Human MX2 is an interferon-induced post-entry inhibitor of HIV-1 infection. Nature 2013, 502, (7472), 559-62.

78. Liu, Z.; Pan, Q.; Ding, S.; Qian, J.; Xu, F.; Zhou, J.; Cen, S.; Guo, F.; Liang, C., The interferon-inducible MxB protein inhibits HIV-1 infection. Cell Host Microbe 2013, 14, (4), 398-410.

79. Kane, M.; Yadav, S. S.; Bitzegeio, J.; Kutluay, S. B.; Zang, T.; Wilson, S. J.; Schoggins, J. W.; Rice, C. M.; Yamashita, M.; Hatziioannou, T.; Bieniasz, P. D., MX2 is an interferon-induced inhibitor of HIV-1 infection. Nature 2013, 502, (7472), 563-6.

80. Matreyek, K. A.; Wang, W.; Serrao, E.; Singh, P. K.; Levin, H. L.; Engelman, A., Host and viral determinants for MxB restriction of HIV-1 infection. Retrovirology 2014, 11, 90.

81. Yan, N.; Regalado-Magdos, A. D.; Stiggelbout, B.; Lee-Kirsch, M. A.; Lieberman, J., The cytosolic exonuclease TREX1 inhibits the innate immune response to human immunodeficiency virus type 1. Nat Immunol 2010, 11, (11), 1005-13.

82. Gao, D.; Wu, J.; Wu, Y. T.; Du, F.; Aroh, C.; Yan, N.; Sun, L.; Chen, Z. J., Cyclic GMP-AMP synthase is an innate immune sensor of HIV and other retroviruses. Science 2013, 341, (6148), 903-6.

83. Woelk, C. H.; Ottones, F.; Plotkin, C. R.; Du, P.; Royer, C. D.; Rought, S. E.; Lozach, J.; Sasik, R.; Kornbluth, R. S.; Richman, D. D.; Corbeil, J., Interferon gene expression following HIV type 1 infection of monocyte-derived macrophages. AIDS Res Hum Retroviruses 2004, 20, (11), 1210-22.

84. Nasr, N.; Maddocks, S.; Turville, S. G.; Harman, A. N.; Woolger, N.; Helbig, K. J.; Wilkinson, J.; Bye, C. R.; Wright, T. K.; Rambukwelle, D.; Donaghy, H.; Beard, M. R.; Cunningham, A. L., HIV-1 infection of human macrophages directly induces viperin which inhibits viral production. Blood 2012, 120, (4), 778-88.

85. Noyce, R. S.; Taylor, K.; Ciechonska, M.; Collins, S. E.; Duncan, R.; Mossman, K. L., Membrane perturbation elicits an IRF3-dependent, interferon-independent antiviral response. J Virol 2011, 85, (20), $10926-31$.

86. Holm, C. K.; Jensen, S. B.; Jakobsen, M. R.; Cheshenko, N.; Horan, K. A.; Moeller, H. B.; Gonzalez-Dosal, R.; Rasmussen, S. B.; Christensen, M. H.; Yarovinsky, T. O.; Rixon, F. J.; Herold, B. C.; Fitzgerald, K. A.; Paludan, 
S. R., Virus-cell fusion as a trigger of innate immunity dependent on the adaptor STING. Nat Immunol 2012, 13, (8), 737-43.

87. Neil, S. J.; Zang, T.; Bieniasz, P. D., Tetherin inhibits retrovirus release and is antagonized by HIV-1 Vpu. Nature 2008, 451, (7177), 425-30.

88. Van Damme, N.; Goff, D.; Katsura, C.; Jorgenson, R. L.; Mitchell, R.; Johnson, M. C.; Stephens, E. B.; Guatelli, J., The interferon-induced protein BST-2 restricts HIV-1 release and is downregulated from the cell surface by the viral Vpu protein. Cell Host Microbe 2008, 3, (4), 245-52.

89. Chu, H.; Wang, J. J.; Qi, M.; Yoon, J. J.; Chen, X.; Wen, X.; Hammonds, J.; Ding, L.; Spearman, P., Tetherin/BST2 is essential for the formation of the intracellular virus-containing compartment in HIV-infected macrophages. Cell Host Microbe 2012, 12, (3), 360-72.

90. Lu, J.; Pan, Q.; Rong, L.; He, W.; Liu, S. L.; Liang, C., The IFITM proteins inhibit HIV-1 infection. J Virol 2011, 85, (5), 2126-37.

91. Jia, R.; Pan, Q.; Ding, S.; Rong, L.; Liu, S. L.; Geng, Y.; Qiao, W.; Liang, C., The N-terminal region of IFITM3 modulates its antiviral activity by regulating IFITM3 cellular localization. J Virol 2012, 86, (24), 13697-707.

92. Tartour, K.; Appourchaux, R.; Gaillard, J.; Nguyen, X. N.; Durand, S.; Turpin, J.; Beaumont, E.; Roch, E.; Berger, G.; Mahieux, R.; Brand, D.; Roingeard, P.; Cimarelli, A., IFITM proteins are incorporated onto HIV-1 virion particles and negatively imprint their infectivity. Retrovirology 2014, 11, 103.

93. Zhang, Y.; Tada, T.; Ozono, S.; Yao, W.; Tanaka, M.; Yamaoka, S.; Kishigami, S.; Fujita, H.; Tokunaga, K., Membrane-associated RING-CH (MARCH) 1 and 2 are MARCH family members that inhibit HIV-1 infection. J Biol Chem 2019, 294, (10), 3397-3405.

94. Pierini, V.; Gallucci, L.; Sturzel, C. M.; Kirchhoff, F.; Fackler, O. T., SERINC5 Can Enhance Proinflammatory Cytokine Production by Primary Human Myeloid Cells in Response to Challenge with HIV-1 Particles. J Virol 2021, 95, (9).

95. Zutz, A.; Scholz, C.; Schneider, S.; Pierini, V.; Munchhoff, M.; Sutter, K.; Wittmann, G.; Dittmer, U.; Draenert, R.; Bogner, J. R.; Fackler, O. T.; Keppler, O. T., SERINC5 Is an Unconventional HIV Restriction Factor That Is Upregulated during Myeloid Cell Differentiation. J Innate Immun 2020, 12, (5), 399-409.

96. Xu, G. G.; Guo, J.; Wu, Y., Chemokine receptor CCR5 antagonist maraviroc: medicinal chemistry and clinical applications. Curr Top Med Chem 2014, 14, (13), 1504-14.

97. Beitari, S.; Ding, S.; Pan, Q.; Finzi, A.; Liang, C., Effect of HIV-1 Env on SERINC5 Antagonism. J Virol 2017, 91, (4).

98. Liu, S. Y.; Aliyari, R.; Chikere, K.; Li, G.; Marsden, M. D.; Smith, J. K.; Pernet, O.; Guo, H.; Nusbaum, R.; Zack, J. A.; Freiberg, A. N.; Su, L.; Lee, B.; Cheng, G., Interferon-inducible cholesterol-25-hydroxylase broadly inhibits viral entry by production of 25-hydroxycholesterol. Immunity 2013, 38, (1), 92-105.

99. Blanc, M.; Hsieh, W. Y.; Robertson, K. A.; Kropp, K. A.; Forster, T.; Shui, G.; Lacaze, P.; Watterson, S.; Griffiths, S. J.; Spann, N. J.; Meljon, A.; Talbot, S.; Krishnan, K.; Covey, D. F.; Wenk, M. R.; Craigon, M.; Ruzsics, Z.; Haas, J.; Angulo, A.; Griffiths, W. J.; Glass, C. K.; Wang, Y.; Ghazal, P., The transcription factor STAT-1 couples macrophage synthesis of 25-hydroxycholesterol to the interferon antiviral response. Immunity 2013, 38, (1), 106-18.

100. Lubow, J.; Collins, K. L., Vpr Is a VIP: HIV Vpr and Infected Macrophages Promote Viral Pathogenesis. Viruses 2020, 12, (8).

101. Cassol, E.; Cassetta, L.; Rizzi, C.; Gabuzda, D.; Alfano, M.; Poli, G., Dendritic cell-specific intercellular adhesion molecule-3 grabbing nonintegrin mediates HIV-1 infection of and transmission by M2a-polarized macrophages in vitro. AIDS 2013, 27, (5), 707-16. 
102. Cicala, C.; Arthos, J.; Fauci, A. S., Role of T-cell trafficking in the pathogenesis of HIV disease. Curr Opin HIV AIDS 2019, 14, (2), 115-120.

103. Murray, P. J.; Allen, J. E.; Biswas, S. K.; Fisher, E. A.; Gilroy, D. W.; Goerdt, S.; Gordon, S.; Hamilton, J. A.; Ivashkiv, L. B.; Lawrence, T.; Locati, M.; Mantovani, A.; Martinez, F. O.; Mege, J. L.; Mosser, D. M.; Natoli, G.; Saeij, J. P.; Schultze, J. L.; Shirey, K. A.; Sica, A.; Suttles, J.; Udalova, I.; van Ginderachter, J. A.; Vogel, S. N.; Wynn, T. A., Macrophage activation and polarization: nomenclature and experimental guidelines. Immunity 2014, 41, (1), 14-20.

104. Cassol, E.; Cassetta, L.; Alfano, M.; Poli, G., Macrophage polarization and HIV-1 infection. J Leukoc Biol 2010, 87, (4), 599-608.

105. Kajaste-Rudnitski, A.; Marelli, S. S.; Pultrone, C.; Pertel, T.; Uchil, P. D.; Mechti, N.; Mothes, W.; Poli, G.; Luban, J.; Vicenzi, E., TRIM22 inhibits HIV-1 transcription independently of its E3 ubiquitin ligase activity, Tat, and NF-kappaB-responsive long terminal repeat elements. J Virol 2011, 85, (10), 5183-96.

106. Turrini, F.; Marelli, S.; Kajaste-Rudnitski, A.; Lusic, M.; Van Lint, C.; Das, A. T.; Harwig, A.; Berkhout, B.; Vicenzi, E., HIV-1 transcriptional silencing caused by TRIM22 inhibition of Sp1 binding to the viral promoter. Retrovirology 2015, 12, 104.

107. Bou Nasser Eddine, F.; Forlani, G.; Lombardo, L.; Tedeschi, A.; Tosi, G.; Accolla, R. S., CIITA-driven MHC class II expressing tumor cells can efficiently prime naive CD4(+) TH cells in vivo and vaccinate the host against parental MHC-II-negative tumor cells. Oncoimmunology 2017, 6, (1), e1261777. 